\title{
Perancangan Aplikasi Rental Mobil Dengan Framework Codelgniter
}

\author{
Putry Wahyu Setyaningsih', Irfan Juliardi Saputra ${ }^{2}$ \\ 1,2Program Studi Sistem Informasi, Universitas Mercu Buana Yogyakarta \\ putryws@mercubuana-yogya.ac.id
}

\begin{abstract}
Abstrak
Rental mobil adalah jenis usaha yang bergerak dalam bidang transportasi persewaan kendaraan roda empat. Dengan adanya perkembangan teknologi saat ini sangat mempengaruhi kualitas dalam bidang jasa sewa mobil. Beberapa bidang yang memanfaatkan teknologi informasi adalah bidang pendidikan, pertanian serta perusahaan-perusahaan telah memanfaatkan teknologi informasi untuk memudahkan informasi yang didapat cepat, tepat dan akurat sampai ke masyarakat. Berkembangnya teknologi tidak hanya digunakan untuk suatu bidang maupun perusahaan berskala besar, namun dapat digunakan oleh berbagai kalangan masyarakat untuk menunjang suatu usaha yang dikelolanya. Usaha yang memanfaatkan teknologi informasi ini salah satunya adalah rental mobil Sakti yang bergerak dalam bidang transportasi untuk jasa persewaan kendaraan roda empat. Saat ini transportasi roda empat sudah menjadi kebutuhan untuk menunjang mobilitas sehari-hari semua kalangan. Pengelolaan data pada Rental Mobil Sakti masih menggunakan cara manual yang sering menimbulkan kesalahan. Perkembangan teknologi juga memungkinkan berkembangnya suatu bahasa pemrograman, salah satunya adalah Framework Codeigniter. Oleh sebab itu penulis merancang sebuah aplikasi rental mobil dengan framework codeigniter yang bertujuan untuk memudahkan pemilik untuk mengelola data mobil, data transaksi dan untuk mencetak laporan transaksi serta terhindar dari kesalahan.
\end{abstract}

Kata kunci: Codeigniter, Framework, Rental Mobil

\begin{abstract}
Car rental is a type of business that is engaged in four-wheeled vehicle rental transportation. With the current technological developments greatly affect the quality in the field of car rental services. Several fields that use information technology are education, agriculture and companies have used information technology to facilitate quick, precise and accurate information to the public. The development of technology is not only used for a field or large-scale company, but can be used by various groups of people to support a business they manage. One of the businesses that utilize this information technology is Sakti car rental, which is engaged in transportation for four-wheeled vehicle rental services. Currently, four-wheeled transportation has become a necessity to support the daily mobility of all people. Data management on Sakti Car Rental still uses manual methods which often cause errors. Technological developments also allow the development of a programming language, one of which is the Codelgniter Framework. Therefore, the author designed a car rental application with a codeigniter framework that aims to make it easier for owners to manage car data, transaction data and to print transaction reports and avoid errors.
\end{abstract}

Keywords: Codeigniter, Framework, Rent Car

\section{Pendahuluan}

Era globalisasi saat ini teknologi informasi sangat berperan penting dalam kehidupan manusia dalam memperbaiki kualitas suatu usaha yang dikelola. Teknologi informasi tidak hanya digunakan oleh perusahaan atau instansi-intansi berskala besar, akan tetapi dapat digunakan pada bidang usaha maupun instansi berskala 
kecil. Alat transportasi saat ini menjadi suatu kebutuhan disemua kalangan masyarakat, salah satu nya adalah kendaraan roda empat atau yang biasa disebut mobil. Kendaraan roda empat saat ini sudah menjadi moda transportasi yang menjadi kebutuhan semua masyarakat untuk menunjang mobilitasnya. Kota Yogyakarta setiap harinya banyak dikunjungi wisatawan maupun kunjungan kerja bagi setiap instansi-instansi dari luar Yogyakarta, dengan banyaknya wisatawan maupun kunjungan kerja membuat usaha rental mobil bermunculan. Para pengusaha rental mobil di daerah Yogyakarta belum sepenuhnya menggunakan teknologi informasi dalam mengelola datanya, sehingga masih sering terjadi kesalahan. Penelitian ini bertujuan untuk merancang sebuah aplikasi rental mobil dengan framework codeigniter yang nantinya akan memudahkan pemilik dalam mengelola data-data dalam rental mobil seperti data mobil, data kostumer serta data transaksi yang pernah terjadi dan mencetak laporan sesuai tanggal yang diinginkan.

\section{Tinjauan Pustaka}

\subsection{Penelitian Terkait}

Penelitian yng dilakukan oleh Henry Firmana Suryowono dalam artikel yang berjudul "Perancangan Sistem Informasi Rental Kendaraan di Kota Kudus Menggunakan Framework Codeigniter" menjelaskan bahwa system informasi yang dibuat telah sesuai dengan yang diharapkan, dimana semua fitur dapat berjalan dengan baik. Hasil dari pengujian menunjukkan jika system informasi ini bermanfaat bagi masyarakat kota Kudus dalam mencari informasi seputar rental kendaraan [1]. Penelitian yang dilakukan oleh Dwi Wahyu Kurniawan dalam artikelnya yang berjudul "Perancangan dan Pembuatan Aplikasi Manajemen Peminjaman Kendaraan Berbasis Web Dengan Framework Codeigniter" menerangkan bahwa berdasarkan pengujian blackbox maka system ini siap digunakan untuk perusahaan yang dapat membantu dalam hal kecepatan proses dan efektivitas proses diperusahaan, karena telah melewati pengujian UAT yang menunjukkan system ini layak untuk digunakan [2].

Penelitian yang dilakukan oleh Chrisma Surya Setya Hariyanto dalam artikelnya yang berjudul "Sistem Informasi Manajemen Rental Mobil F3 Rent Car Berbasis Framework Codeigniter" menerangkan bahwa dengan adanya system ini proses pendataan transaksi pada F3 Rent Car lebih aman dan dapat meminimalisir kehilangan data. Mempermudah pengecekan ketersediaan mobil yang bebas dan sedang berjalan [3].

Penelitian yang dilakukan oleh Nur Afifah dalam artikelnya yang berjudul "Pembangunan Website Pengelolaan Kegiatan Komunitas menggunakan Framework Codelgniter (Studi Kasus : Komunitas Generasi Baru Inonesia Malang)", 
menjelaskan bahwa pada tahap rekayasa kebutuhan didapatkan 7aktor dan 57 kebutuhan fungsional. Pada tahap perancangan didapatkan beberapa model perangkat lunak dan pada tahap pengujian dilakukan pengujian unit pada 3 sampel uji dengan 2 jalur kasus uji menggunakan basic path testing yang memberi hasil valid. Kemudian dilakukan pengujian integrase pada 1 sampel uji menggunakan strategi top-down yang memberi hasil valid. Kemudian 57 kebutuhan fungsional system di uji validitasnya menggunakan metode black box testing yang memberikan hasil valid. Selain itu dilakukan pengujian compability menggunakan tool SortSite memberikan hasil berupa 100\% konten dan fungsionalitas system dapat berfungsi [4].

Penelitian yang dilakukan oleh Husein Abdul Qodir Yahya dalam artikelnya yang berjudul "Rancang Bangun Aplikasi Perpustakaan Menggunakan Framework Code Igniter (Studi Kasus SDN CIBUBUR 05), menerangkan bahwa dengan adanya aplikasi web perpustakaan dapat meringankan serta mengefektifitaskan kinerja-kinerja staff dibagian perpustakaan, baik itu dalam proses pendaftaran anggota maupun proses transaksi peminjaman dan pengembalian buku. Proses transaksi pengembalian buku pun lebih efisien dan tidak memakan waktu lama serta memperkecil kemungkinan hilangnya data transaksi yang disebabkan oleh rusak atau hilangnya dokumen transaksi [5].

\subsection{Landasan Teori}

Codeigniter adalah kerangka kerja pengembangan aplikasi PHP berdasarkan arsitektur yang terstruktur. Codeigniter memiliki tujuan untuk memberikan alat bantu yang dibutuhkan seperti helpers and libraries untuk mengimplementasi tugas yang biasa dilakukan. Dengan demikian, pengembangan proyek menjadi lebih mudah dan cepat. Dan pengembang tidak perlu menulis lagi dari awal [6].

Keuntungan menggunakan Codelgniter yang merupakan sebuah toolkit yang ditujukan untuk orang yang ingin membangun aplikasi web dalam bahasa pemrograman PHP [7]. Beberapa keunggulan yang ditawarkan oleh Codelgniter adalah sebagai berikut :

a. Codelgniter adalah framework yang bersifat free dan opensource.

b. Codelgniter memilikiukuran yang kecil dibandingkan dengan framework lain. Setelah proses instalasi, framework Codelgniter hanya berukuran kurang lebih 2 MB. Dokumentasi Codelgniter memiliki ukuran sekitar $6 \mathrm{MB}$.

c. Aplikasi yang dibuat menggunakan Codelgniter bisa berjalan cepat.

d. Codelgniter menggunakan pola desain Model-View-Controller (MVC) sehingga 
satu file tidak terlalu berisi banyak kode. Hal ini menjadikan kode lebih mudah dibaca, dipahami, dan dipelihara dikemudian hari.

e. Codelgniter dapat diperluas sesuai dengan kebutuhan.

f. Codelgniter terdokumentasi dengan baik. Informasi tentang pustaka kelas dan fungsi yang disediakan oleh Codelgniter dapat diperoleh melalui dokumentasi yang disertakan di dalam paket distribusinya

Model-View-Controller atau MVC adalah sebuah metode untuk membuat sebuah aplikasi dengan memisahkan data (Model) dari tampilan (View) dan cara bagaimana memprosesnya (Controller). Dalam implementasi kebanyakan framework dalam aplikasi web adalah berbasis arsitektur MVC (Model-View-Control) [8]

Salah satu konsep yang dibuat oleh pakar pemrograman adalah memecah sebuah aplikas web menjadi tiga bagian yaitu model yang berkaitan dengan operasi yang berhubungan dengan basis data, view yang berhubungan dengan antarmuka aplikasi dan terakhir controller yang berhubungan dengan logika aplikasi dan mengendalikan alur data antara view dan controller konsep ini merupakan pengembangan dari konsep pemrograman berorientasi objek dan dalam pemrograman dikenal dengan MVC [9]
Pola MVC memecah aplikasi menjadi tiga modul: Model View Controller. Gambar 1 menggambarkan arsitektur kerangka kerja PHP untuk manajemen basis data berdasarkan MVC [10].

\section{Metode Penelitian}

Metode yang digunakan dalam perancangan system aplikasi rental mobil dengan framework codeigniter memiliki langkah-langkah sebagai berikut :

a. Melakukan pengumpulan data tentang informasi Rental Mobil Sakti yang lokasinya berada pada Jl. Kapten Hariyadi Ngaglik Sleman 5581

b. Perancangan dengan koding PHP dan database MySQL

c. Mengimplementasikan Framework Codelgniter dalam aplikasi Rental Mobil Sakti yang telah dibuat.

d. Testing atau pengujian dilakukan untuk menemukan error yang ada pada system.

e. Dilakukan maintenance secara rutin supaya aplikasi Rental Mobil Sakti tetap beroperasi.

Penelitian ini dilakukan melalui 3 tahap. Alurnya seperti pada gambar 1. 


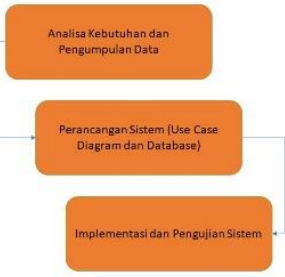

Gambar 1. Tahap Penelitian

Pada tahap pertama pada penelitian ini adalah analisa kebutuhan dan pengumpulan data. Analisa kebutuhan dengan cara mewawancarai pemilik atau pengelola dari system aplikasi yang akan dibuat nanti dengan menyesuaikan apa saja kebutuhan dari pengelola. Untuk pengumpulan data, peneliti akan meminta informasi data mobil, data kostumer dan data transaksi.

Tahap kedua yaitu membuat perancangan system salah satunya adalah UML dan database.

Use Case Diagram pada system ini ada Actor dan Use Case nya. Dimana actor dapat mengelola semua data yang ada di system. Use case diagram dapat dilihat pada gambar 2 .

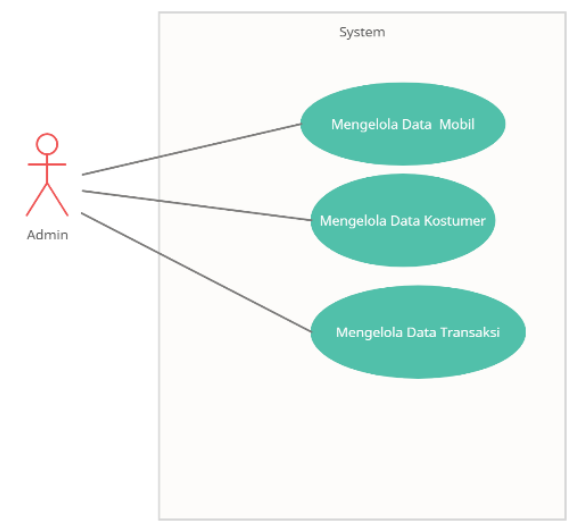

Gambar 2. Use Case Diagram
Pada database terdapat data admin, data mobil, data transaksi dan data kostumer. Gambar databasenya dapat dilihat pada gambar 3 .

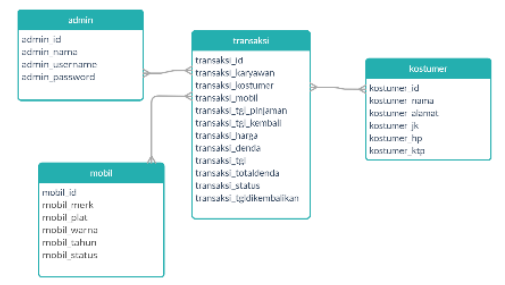

Gambar 3. Database Rental Mobil

Tahap yang terakhir adalah implementasi system dan pengujian system.

\section{Hasil dan Pembahasan}

Semua tahapan dari perancangan aplikasi rental mobil disusun secara sistematis, dimulai dari wawancara pemilik untuk Analisa kebutuhan system, pembuatan database, pembuatan tabel dan pengujian di server localhost.

1. Tampilan halaman pertama pada system aplikasi ini adalah halaman login, dimana admin harus memasukkan username dan password, jika username dan password salah akan ada notifikasi. Halaman login dapat dilihat pada gambar 4 .

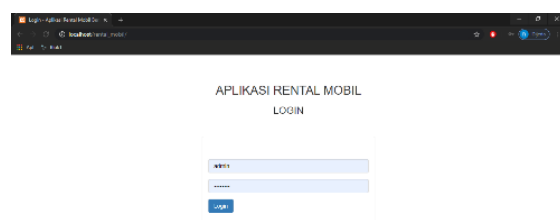

Gambar 4. Halaman Login

2. Admin juga dapat memperbarui passwordnya. Seperti gambar 5 di bawah ini 


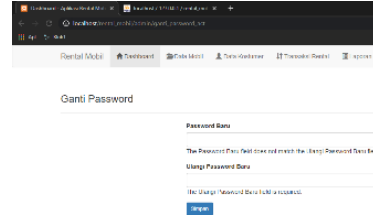

Gambar 5. Ganti Password

3. Jika sudah selesai, admin dapat melakukan proses logout seperti gambar 6 di bawah ini
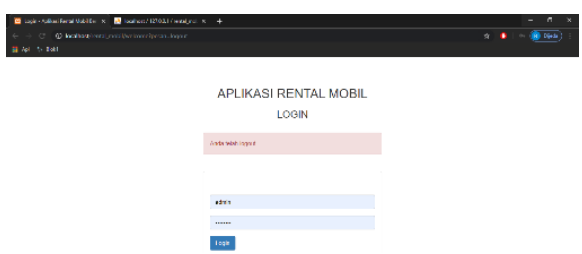

Gambar 6. Halaman Logout

4. Admin dapat menambahkan data mobil baru, halaman tambah data mobil baru dapat dilihat pada gambar 7

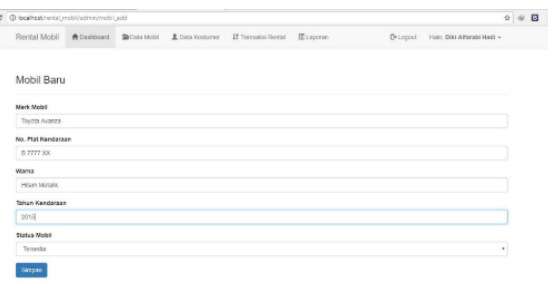

Gambar 7. Data Mobil Baru

5. Setelah admin memasukkan data mobil baru, maka sistem akan menyimpan.

Tampilan data mobil berhasil disimpan seperti gambar 8 .

$$
\text { Data Mobi }
$$

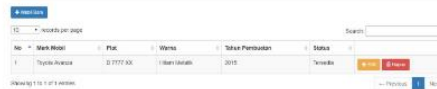

Gambar 8. Berhasil Simpan Data Mobil

6. Admin juga dapat merubah data mobil. Setelah admin klik edit pada system akan muncul tampilan halamannya seperti gambar 9.

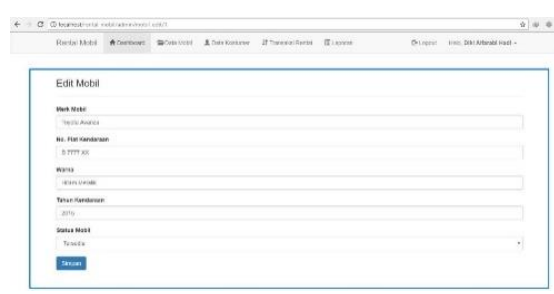

Gambar 9. Edit Data Mobil

7. Setelah admin mengubah nama mobil dari toyota avanza ke honda jazz, maka tampilan halamannya akan seperti gambar 10.

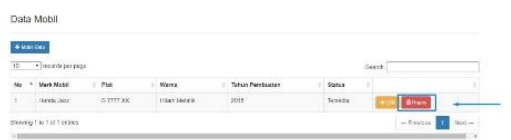

Gambar 10. Berhasil Edit Data Mobil

8. Admin juga dapat menghapus data mobil. Tampilannya akan seperti gambar 11 .

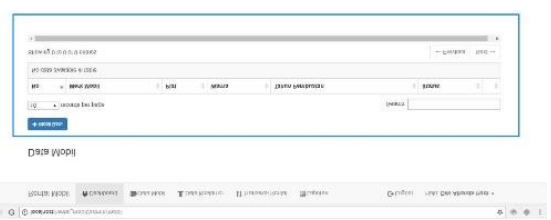

Gambar 11. Berhasil Hapus Data Mobil

9. Halaman admin menambahkan data kostumer baru dapat dilihat pada gambar 12 .

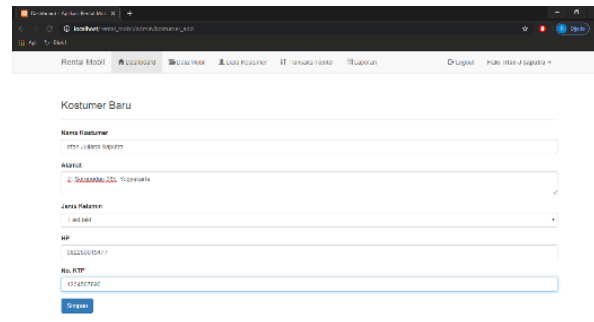

Gambar 12. Tambah Kostumer Baru

10. Setelah admin berhasil memasukkan data kostumer baru. Pada data kostumer, admin juga dapat mengubah serta menghapus 
data. Tampilan halaman data kostumer seperti gambar 13 .

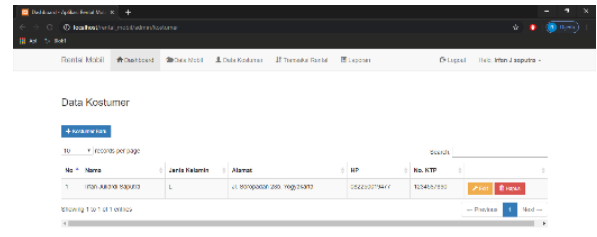

Gambar 13. Data Kostumer Baru

11. Halaman untuk admin memasukkan data transaksi baru seperti gambar 14.

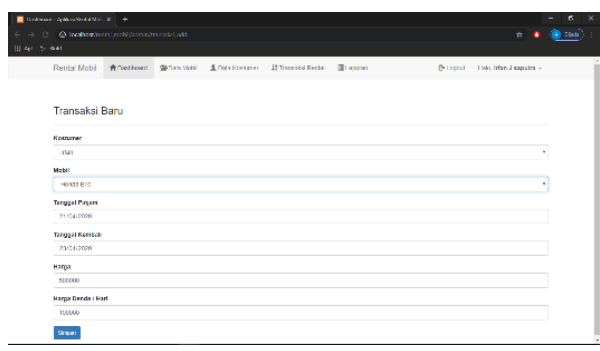

Gambar 14. Transaksi Baru

12. Setelah admin berhasil memasukkan data transaksi baru, tampilan seperti gambar 15 . Pada data transaksi, admin dapat mengubah dan menghapus data transaksi.

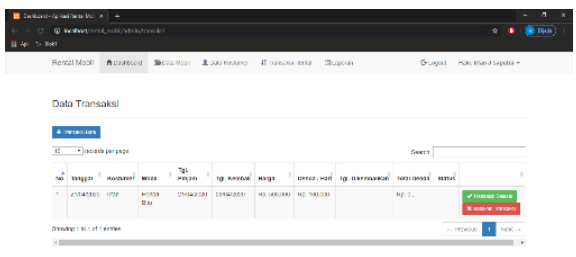

Gambar 15. Data Transaksi Baru

13. Pada laporan, admin dapat mencetak sesuai tanggal yang diinginkan. Tampilan halamannya seperti gambar 16 .

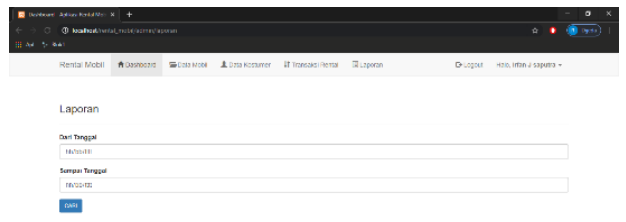

Gambar 16. Halaman Laporan
14. Setelah admin memasukkan tanggal laporan yang ingin dicetak, maka tampilan halamannya akan seperti gambar 17 .

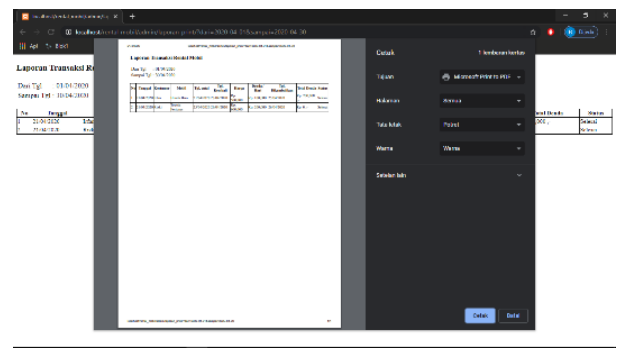

Gambar 17. Cetak Laporan

\section{Kesimpulan}

Kesimpulan hasil dari penelitian ini adalah peneliti berhasil membuat sebuah perancangan aplikasi rental mobil yang memudahkan pemilik dalam mengelola data mobil, data kostumer, data transaksi dan mencetak laporan transaksi serta mengurangi resiko terjadinya Human Error.

\section{Daftar Pustaka}

[1] Suryowono, Henry Firmana. "Perancangan Sistem Informasi Rental Kendaraan di Kota Kudus Menggunakan Framework Codelgniter," 2016. https://repository.uksw.edu/handle/12345678 9/9588

[2] Kurniawan, Dwi W. dan Irsyadi, Fatah Y. "Perancangan dan Pembuatan Aplikasi Manajemen Peminjaman Kendaraan Berbasis Web Dengan Framework Codeigniter,", Emitor : Jurnal Teknik Elektro, Vol. 21 No. 01 Maret 2021, hal 49-53. 
[3] Chrisma Surya Setya Hariyanto. 2021. Sistem Informasi Manajemen Rental Mobil F3 Rent Car Berbasis Framework Codeigniter. Skripsi. Universitas Semarang. Semarang. [4] Afifah. Nur, Rusdianto. S, dan Rachmadi. A, "Pembangunan Website Pengelolaan Kegiatan Komunitas Menggunakan Framework Codelgniter (Studi Kasus: Komunitas Generasi Baru Indonesia Malang)," Jurnal Pengembangan Teknologi Informasi dan IImu Komputer, Vol.4, No.5, hal 1344-1353, 2020

[5] Yahya. Husein, A.Q, "Rancang Bangun Aplikasi Perpustakaan Menggunakan Framework Codelgniter (Studi Kasus SDN Cibubur 05)," Jurnal Sistem Informasi dan Sains Teknologi, Vol.2, No.2, 2020.

[6] Arrhioui. K, Mbarki. S, Roubi. S, and Erramdani. M, "A Model Driven Approach for Modeling and Gemerating PHP Codelgniter based Applications," Transaction On Machine Learning And Artificial Intelligence, vol. 5, no.2, pp. 259-266, 2017.

[7] Budi Raharjo.Belajar Otodidak Framework Codelgniter : Teknik Pemrograman Web Dengan PHP Dan Framewok Codelgniter $3 /$ Budi Raharjo .2016

[8] Mualim. W, dan Putra, G.U, "Implementasi Framework MVC Pada Sistem Informasi Akademik Di STMIK Yadika Bangil," SPIRIT, vol.9, no.2, hal 35-39. 2017.
[9] Hasyrif SY, Rismayani. 2016. Penerapan Konsep MVC Pada Aplikasi Web Menggunakan Framework Laravel. PROSIDING SEMINAR ILMIAH SISTEM INFORMASI DAN TEKNOLOGI INFORMASI Vol. V, No. 2 Agustus 2016 : 174 - 183.

[10] Chanchai Supaartagorn. 2011. PHP FRAMEWORK FOR DATABASE MANAGEMENT BASED ON MVC PATTERN. International Journal of Computer Science \& Information Technology (IJCSIT), Vol 3, No 2, April 2011. DOI : 10.5121/ijcsit.2011.3219

[11] Rashidah F.Olanrewaju, Thouhedul Islam dan Nor'ashikin Bte. Ali. 2014. AN EMPIRICAL STUDY OF THE EVOLUTION OF PHP MVC FRAMEWORK. Retrieved from

https://link.springer.com/chapter/10.1007\%2 F978-3-319-07674-4_40

[7] Irawan. R, dan Sulistyowati. "Implementasi Framework Codelgniter Untuk Pengembangan Website Pada Dinas Perkebunan Provinsi Kalimantan Tengah," Saintekom, Vol.7, No.1, hal 67-80, 2017.

[8] Koespradono, dkk. 2013. "Sistem Informasi Pengolahan Data Pertumbuhan Ekonomi Dan Ketimpangan Di Kabupaten Klaten (Tahun 2003-2012) Menggunakan Framework Codeigniter". Jurnal SCRIPT Vol 1 No 1. 
Teknik Informatika, institute Sains \& Teknologi AKPRIND. Yogyakarta.

[9] Solanki, N., Shah, D., \& Shah, A. (2017). A Survey on different Framework of PHP. International Journal of Latest Technology in Engineering, Management \& Applied Science (IJLTEMAS), 155-158.

[10] Subari. A, Tadeus. D.Y, Winarno. $H$, dan Yuwono, T. "Rancang Bangun Sistem Administrasi Kerja Praktek Dan Tugas Akhir Berbasis Web Menggunakan Framework Codelgniter," Gema Teknologi, Vol.19, No.4, 2017.

[11] Suhartini, Sadali. M, dan Putra. Y. K. "Sistem Informasi Berbasis Web Sma AlMukhtariyah Mamben Lauk Berbasis Php dan Mysql Dengan Framework Codeigniter," Infotek, Vol.3 No.1, hal 79-83, Januari 2020.

[12] CP. Bq. A, Fathurriadi, dan Ahmadi. H. "Rancang Bangun Sistem Pengiriman Berkas Bermasalah Berbasis Online Di Dinas Kependudukan Dan Pencatatan Sipil Kabupaten Lombok Timur," Infotek, Vol.3 No.1, hal 20-26, Januari 2020.
[13] Rahman, F. dan Ratna, Silvia. "Perancangan E-Learning Berbasis Web Menggunakan Framework Codeigniter," Technologia, Vol 9, No.2, April-Juni 2018.

[14] Alfi Nur Rohmat. 2016. Sistem Informasi Akademik Dengan Framework Codeigniter. Skripsi. Universitas Muhammadiyah Surakarta. Surakarta.

[15] Afuan, L. "Pemanfaatan Framework Codeigniter dalam Pengembangan Sistem Informasi Pendataan Laporan Kerja Praktek Mahasiswa Program Studi Teknik Informatika Unsoed," JUITA, Vol. 1 Nomor 2, November 2010 , hal $39-44$.

[16] A. Sudianto and H. Ahmadi, "Rancang Bangun Sistem Informasi Penjualan Sparepart Motor Pada Bengkel Vinensi Motor Berbasis Web Guna Meningkatkan Penjualan dan Promosi Produk Pendahuluan Vinensi sepeda motor motor merupakan yang toko cukup kebutuhan suku cadang motor juga dibutuhkan s," Infotek J. Inform. dan Teknol., vol. 3, no. 2, pp. 32-39, 2020. 